\title{
Analisa Potensi Bahaya pada Perusahaan Fabrikasi Baja menggunakan Metode HAZOP (Hazard and Operability Study)
}

\author{
Hastawati Chrisna Suroso, Kukuh Eska Yanuar \\ Jurusan Teknik Industri, Fakultas Teknologi Industri, Institut Teknologi Adhi Tama Surabaya, \\ J1. Arif Rahman Hakim 100, Surabaya, 60117, Indonesia \\ chrisna.suroso@itats.ac.id
}

\begin{abstract}
Abstrak
Dalam perusahaan fabrikasi baja masih banyak risiko yang dapat menyebabkan kecelakaan kerja. Hal ini dikarenakan para pekerja berhubungan langsung dengan benda dan alat berat pada saat bekerja. Metode yang digunakan dalam penelitian ini untuk menganalisa kecelakaan kerja adalah dengan HAZOP (Hazard and Operability Study) dikarenakan metode ini mampu memunculkan potensi kecelakaan dalam tempat kerja. Tujuan dari penelitian ini adalah mengetahui jenis kecelakaan kerja yang dominan pada perusahaan serta mengetahui faktor utama penyebab terjadinya kecelakaan kerja tersebut. Hasil dari penelitian ini adalah kecelakaan kerja mata terpercik geram menjadi jenis kecelakaan yang paling dominan diantara jenis kecelakaan lainnya sedangkan faktor utama terjadinya kecelakaan kerja adalah kurangnya pemakaian APD yang dapat ditinjau lebih lanjut dari beberapa aspek yaitu manusia, metode, dan material.
\end{abstract}

Kata kunci: HAZOP, kecelakaan kerja, hazard, risk, fabrikasi baja

\section{Pendahuluan}

Perkembangan sektor industri di Indonesia memiliki dampak positif terhadap penyerapan tenaga kerja, peningkatan pendapatan, serta pemerataan pembangunan. Akan tetapi dampak lain dari perkembangan sektor industri ini juga akan menghadirkan faktor-faktor risiko bahaya yang terjadi di lingkungan kerja. Salah satunya, pada perusahaan fabrikasi baja masih banyak risiko yang dapat menyebabkan terjadinya kecelakaan kerja dikarenakan para pekerja berhubungan langsung dengan benda dan alat berat selama proses bekerja.

Telah banyak metode untuk megetahui risiko kecelakaan kerja berdasarkan karakteristik yang sesuai dengan masing-masing situasi dan kondisi lingkungan kerja. Pada permasalahan kali ini Hazard and Operability (HAZOP) dirasa sebuah tools yang sesuai dalam mengidentifikasi risiko dikarenakan mampu mengidentifikasi hazard yang terjadi pada perusahaan atau potensi adanya kecelakaan kerja (Dunjó, dkk., 2010). HAZOP merupakan sebuah teknik analisa bahaya yang diperuntukkan dalam persiapan penerapan sistem keamanan yang baru atau sebuah perbaharuan sistem dari potensi bahaya yang ada atau permasalahan pada operabilitas sistem tersebut (Khamid, dkk., 2019). HAZOP juga merupakan sebuah tools yang sistematis, dilakukan berdasarkan pendekatan sistematik yang memberikan sebuah nilai dari keselamatan dan proses pengoperasian peralatan produksi maupun sebuah sistem yang kompleks (Febriyan, dkk., 2017).

Tujuan penelitian ini adalah mengetahui faktor penyebab terjadinya kecelakaan kerja yang paling dominan di perusahaan serta mencari faktor penyebab utama dari kecelakaan kerja tersebut. Dengan metode HAZOP, maka diharapkan dapat dengan mudah menganalisa jenis jenis hazard di perusahaan berdasarkan dengan task yang dilakukan para pekerja di setiap divisi yang selanjutnya akan diproses dengan risk matriks untuk mengetahui tingkat keparahan dari penyebab terjadinya kecelakaan kerja yang dominan (Kotek and Tabas, 2012). HAZOP juga mampu mengenali peluang hazard yang terjadi sepanjang proses di perisahaan (Hamdy dan Tanjung, 2016). Pada penelitian sebelumnya penggunaan HAZOP seringkali masih belum mengulas tentang hazard, consequence, action, dan recovery pada sebuah tabel. Tabel ini diharapkan akan memberikan sebuah acuan bagi perusahaan terhadap langkah 
utama yang harus dilakukan apabila hazard sejenis sedang terjadi dan juga membantu memberikan daftar hazard yang sering terjadi di perusahaan. Breakdown mengenai jenis-jenis hazard diberikan dan disajikan pada diagram pareto yang nantinya akan diteliti lebih lanjut mengenai faktor utama penyebab hazard yang dominan. Pada penelitian ini proses stratifikasi sangat ditekankan dengan menggunakan tabel HAZOP yang kemudian ditunjang oleh diagram pareto dalam penyajiannya.

\section{Metode Penelitian}

\subsection{Pengumpulan Data}

Penelitian ini dilakukan pada perusahaan fabrikasi baja dengan PT. Swadaya Graha sebagai objek penelitian. Pengambilan data dilakukan berdasarkan wawancara dan observasi langsung kepada pihak HRD dan karyawan. Beberapa data yang diambil adalah sebagai berikut:

a. Prosedur fabrikasi baja, peralatan, dan fasilitas APD yang dimiliki dan digunakan oleh karyawan

b. Pembagian divisi pada perusahaan fabrikasi baja

c. Jenis-jenis hazard yang telah dan pernah terjadi pada masing-masing divisi

\subsection{Analisa Risiko HAZOP}

Metode HAZOP dirasa cocok dengan keadaan perusahaan fabrikasi baja dan mampu mengidentifikasi risiko dengan cara yang terstruktur dan rapi. Langkah-langkah dalam melakukan HAZOP adalah sebagai berikut (Dian \& Resti, 2015):

a. Membuat klasifikasi potensi bahaya yang ditemukan pada sebuah sistem (mencari sumber dari potensi adanya bahaya dan seringnya ditemukan potensi tersebut).

b. Membuat deskripsi dari ketidaksesuaian dari awal hingga akhir proses operasi.

c. Membuat deskripsi dari adanya ketidaksesuaian yang terjadi.

d. Membuat sebuah deskripsi dari tindakan sementara yang bisa dilakukan.

e. Menentukan nilai risiko (risk asessment) dengan mempertimbangkan kriteria Likelihood (kemungkinan) dan Consequences (keparahan).

f. Membuat ranking dari kemungkinan terjadinya bahaya yang dikenali dari tabel HAZOP dengan mengkalkulasi nilai likelihood dan consequences, selanjutnya penggunaan risk matrix untuk mengetahui kemungkinan adanya bahaya yang paling dominan untuk diberikan perhatian khusus dan lebih.

\subsection{Penentuan Matriks Risiko (Risk Asessment)}

Untuk merubah skala deskriptif menjadi skala kuantitatif ketentuan yang digunakan adalah berdasarkan aspek pekerja dan lingkungan seperti pada tabel 1 yang menunjukkan likelihood dan Tabel 1 konsekuensi bagi pekerja dan lingkungan.

Tabel 1. Likelihood

\begin{tabular}{clll}
\hline Tingkatan & \multicolumn{1}{c}{ Kriteria } & \multicolumn{1}{c}{$\begin{array}{c}\text { Deskripsi } \\
\text { Keparahan cacat/luka }\end{array}$} & \multicolumn{1}{c}{ Hari Kerja } \\
\hline 1 & $\begin{array}{l}\text { Tidak } \\
\text { signifikan } \\
\text { (insignificant) }\end{array}$ & $\begin{array}{l}\text { Sebuah kejadian yang tidak menyebabkan cacat/luka } \\
\text { pada pekerja }\end{array}$ & $\begin{array}{l}\text { Tidak menyebabkan } \\
\text { kehilangan hari kerja }\end{array}$ \\
2 & Kecil (minor) & $\begin{array}{l}\text { Menyebabkan cacat/luka kecil, kerugian yang sedikit } \\
\text { dan tidak ada dampak yang besar pada proses bisnis }\end{array}$ & $\begin{array}{l}\text { Pekerja masih mampu } \\
\text { bekja pada periode } \\
\text { waktu yang sama }\end{array}$ \\
& Sedang & $\begin{array}{l}\text { Terluka/cacat yang berat dan harus dirawat di rumah } \\
\text { sakit akan tetapi tidak ada cacat permanen, namun } \\
\text { (moderate })\end{array}$ & $\begin{array}{l}\text { Tidak bisa bekerja } \\
\text { kenyebabkan kerugian keuangan yang sedang } 3 \text { hari }\end{array}$ \\
\hline
\end{tabular}


Tabel 1. Likelihood (lanjutan)

\begin{tabular}{|c|c|c|c|}
\hline \multirow{2}{*}{ Tingkatan } & \multirow{2}{*}{ Kriteria } & \multicolumn{2}{|l|}{ Deskripsi } \\
\hline & & Keparahan cacat/luka & Hari Kerja \\
\hline 4 & Berat (major) & $\begin{array}{l}\text { Menyebabkan cacat/luka yang parah dan cacat } \\
\text { permanen serta kerugian keuangan yang besar } \\
\text { terhadap bisnis }\end{array}$ & $\begin{array}{l}\text { Tidak bisa bekerja } \\
\text { lebih dari } 3 \text { hari }\end{array}$ \\
\hline 5 & $\begin{array}{l}\text { Bencana } \\
\text { (catastropic) }\end{array}$ & $\begin{array}{l}\text { Menyebabkan korban kehilangan nyawa dan kegiatan } \\
\text { bisnis bisa berhenti permanen }\end{array}$ & $\begin{array}{l}\text { Kehilangan hari kerja } \\
\text { selamanya }\end{array}$ \\
\hline
\end{tabular}

Tabel 2. Consequences

\begin{tabular}{|c|c|c|c|}
\hline \multirow{2}{*}{ Tingkatan } & \multirow{2}{*}{ Kriteria } & \multicolumn{2}{|l|}{ Deskripsi } \\
\hline & & Kualitatif & Semi Kualitatif \\
\hline 1 & Jarang Terjadi & $\begin{array}{l}\text { Mampu dipertimbangkan tidak hanya pada } \\
\text { keadaan yang berlebihan }\end{array}$ & $\begin{array}{l}\text { Kurang dari } 1 \text { kali dalam } 10 \\
\text { tahun }\end{array}$ \\
\hline 2 & $\begin{array}{l}\text { Kemungkinan } \\
\text { Kecil }\end{array}$ & $\begin{array}{l}\text { Saat ini belum ada kejadian namun bisa } \\
\text { terjadi pada suatu saat }\end{array}$ & Terjadi 1 kali tiap 10 tahun \\
\hline 3 & Mungkin & $\begin{array}{l}\text { Semestinya terjadi dan ada kemungkinan } \\
\text { sudah terjadi di bagian lain }\end{array}$ & $\begin{array}{l}1 \text { kali tiap } 5 \text { tahun sampai } 1 \\
\text { kali tiap tahun }\end{array}$ \\
\hline 4 & $\begin{array}{l}\text { Kemungkinan } \\
\text { Besar }\end{array}$ & $\begin{array}{l}\text { Bisa terjadi dengan gampang, kemungkinan } \\
\text { terjadi pada keadaan tertentu }\end{array}$ & $\begin{array}{l}\text { Lebih dari } 1 \text { kali tiap tahun } \\
\text { hingga } 1 \text { kali tiap bulan }\end{array}$ \\
\hline 5 & Hampir Pasti & Kerap sekali terjadi & Lebih dari 1 kali tiap bulan \\
\hline
\end{tabular}

\subsection{Analisa Matriks Risiko}

Penentuan matriks tingkat risiko menggunakan perkalian antara kemungkinan terjadinya kecelakaan yang berdampak pada lingkungan dengan konsekuensi yang terjadi pada kejadian kecelakaan bagi pekerja dan berdampak bagi lingkungan (Dian \& Resti, 2015).

$R=P \times C$

Dimana :

$R=$ Tingkat Risiko (Rendah, Sedang, Tinggi, Ekstrim)

$P=$ Nilai kemungkinan (1 sampai 5)

$C=$ Nilai konsekuensi (1 sampai 5)

\section{Hasil dan Pembahasan}

Dalam usaha mengidentifikasi kemungkinan adanya bahaya yang mungkin terjadi dalam perusahaan fabrikasi baja ini, maka diperlukan alur proses produksi di perusahaan tersebut. Tabel 3 merupakan hasil identifikasi hazard apa saja yang mungkin terjadi pada setiap stasiun produksi di perusahaan.

Tabel 3. Identifikasi Hazard dan Risk

\begin{tabular}{|c|c|c|c|c|c|}
\hline No & Task & Hazard & Consequence & Action & Recovery \\
\hline 1 & $\begin{array}{l}\text { Melakukan } \\
\text { proses } \\
\text { pengelasan }\end{array}$ & $\begin{array}{l}\text { Mata terpercik } \\
\text { geram }\end{array}$ & $\begin{array}{l}\text { Mata perih, } \\
\text { iritasi }\end{array}$ & $\begin{array}{l}\text { Pemberian pertolongan } \\
\text { pertama pada } \\
\text { kecelakaan. Apabila } \\
\text { tidak memungkinkan } \\
\text { maka dirujuk ke RS } \\
\text { terdekat }\end{array}$ & $\begin{array}{l}\text { Pekerja } \\
\text { dibawa ke } \\
\text { ruang } \\
\text { kesehatan }\end{array}$ \\
\hline 2 & $\begin{array}{l}\text { Melakukan } \\
\text { Proses } \\
\text { pembubutan }\end{array}$ & $\begin{array}{l}\text { Tangan terkena } \\
\text { ulir }\end{array}$ & $\begin{array}{l}\text { Adanya luka } \\
\text { sobek }\end{array}$ & $\begin{array}{l}\text { Pemberian pertolongan } \\
\text { pertama pada } \\
\text { kecelakaan }\end{array}$ & $\begin{array}{l}\text { Pekerja } \\
\text { dibawa ke } \\
\text { ruang } \\
\text { kesehatan }\end{array}$ \\
\hline
\end{tabular}


Tabel 3. Identifikasi Hazard dan Risk (lanjutan)

\begin{tabular}{|c|c|c|c|c|c|}
\hline No & Task & Hazard & Consequence & Action & Recovery \\
\hline 3 & $\begin{array}{l}\text { Melakukan } \\
\text { penggerindaan }\end{array}$ & $\begin{array}{l}\text { Mata terpercik } \\
\text { geram }\end{array}$ & $\begin{array}{l}\text { Mata iritasi, } \\
\text { mata perih, }\end{array}$ & dirujuk ke RS & $\begin{array}{l}\text { Pekerja } \\
\text { dibawa ke } \\
\text { ruang } \\
\text { kesehatan }\end{array}$ \\
\hline 4 & $\begin{array}{l}\text { Melakukan } \\
\text { material } \\
\text { handling }\end{array}$ & $\begin{array}{l}\text { Beban cukup } \\
\text { tinggi, kurang } \\
\text { berhati- hati }\end{array}$ & $\begin{array}{l}\text { Kuku } \\
\text { terkelupas }\end{array}$ & $\begin{array}{l}\text { Pemberian pertolongan } \\
\text { pertama pada } \\
\text { kecelakaan, } \\
\text { dipersilahkan } \\
\text { beristirahat }\end{array}$ & $\begin{array}{l}\text { Pekerja } \\
\text { dibawa ke } \\
\text { ruang } \\
\text { kesehatan }\end{array}$ \\
\hline 5 & $\begin{array}{l}\text { Melakukan } \\
\text { pelubangan } \\
\text { pada baja }\end{array}$ & $\begin{array}{l}\text { Salah komunikasi } \\
\text { dengan pekerja }\end{array}$ & $\begin{array}{l}\text { Bagian tubuh } \\
\text { bengkak }\end{array}$ & Pemberian obat nyeri & $\begin{array}{l}\text { Pekerja } \\
\text { dibawa ke } \\
\text { ruang } \\
\text { kesehatan }\end{array}$ \\
\hline 6 & $\begin{array}{l}\text { Transportasi } \\
\text { pada material }\end{array}$ & $\begin{array}{l}\text { Kurang fokus } \\
\text { saat bekerja }\end{array}$ & $\begin{array}{l}\text { Adanya luka } \\
\text { robek }\end{array}$ & $\begin{array}{l}\text { Pemberian pertolongan } \\
\text { pertama, dan } \\
\text { diperbolehkan kembali } \\
\text { bekerja }\end{array}$ & $\begin{array}{l}\text { Pekerja } \\
\text { dibawa ke } \\
\text { ruang } \\
\text { kesehatan }\end{array}$ \\
\hline 7 & $\begin{array}{l}\text { Melakukan } \\
\text { penggerindaan }\end{array}$ & $\begin{array}{l}\text { Area terbuka } \\
\text { disertai angin } \\
\text { yang kencang }\end{array}$ & Mata iritasi & Dirujuk ke RS & $\begin{array}{l}\text { Pekerja } \\
\text { dibawa ke } \\
\text { ruang } \\
\text { kesehatan }\end{array}$ \\
\hline 8 & $\begin{array}{l}\text { Cutting } \\
\text { marking }\end{array}$ & $\begin{array}{l}\text { Beban terlalu } \\
\text { berat }\end{array}$ & $\begin{array}{l}\text { Kecetit, } \\
\text { kesleo }\end{array}$ & $\begin{array}{l}\text { Dirujuk ke RS dan } \\
\text { diperbolehkan pulang }\end{array}$ & $\begin{array}{l}\text { Pekerja } \\
\text { dibawa ke } \\
\text { ruang } \\
\text { kesehatan }\end{array}$ \\
\hline 9 & $\begin{array}{l}\text { Melakukan } \\
\text { penggerindaan }\end{array}$ & $\begin{array}{l}\text { Kurangnya } \\
\text { komunikasi antar } \\
\text { pekerja }\end{array}$ & $\begin{array}{l}\text { Mata iritasi, } \\
\text { mata perih }\end{array}$ & $\begin{array}{l}\text { Pemberian pertolongan } \\
\text { pertama }\end{array}$ & $\begin{array}{l}\text { Pekerja } \\
\text { dibawa ke } \\
\text { ruang } \\
\text { kesehatan }\end{array}$ \\
\hline 10 & $\begin{array}{l}\text { Melakukan } \\
\text { proses } \\
\text { pengelasan }\end{array}$ & $\begin{array}{l}\text { Beban terlalu } \\
\text { berat }\end{array}$ & $\begin{array}{l}\text { Cidera kaki } \\
\text { kesleo }\end{array}$ & $\begin{array}{l}\text { Pemberian obat nyeri, } \\
\text { dan diperbolehkan } \\
\text { istirahat }\end{array}$ & $\begin{array}{l}\text { Pekerja } \\
\text { dibawa ke } \\
\text { ruang } \\
\text { kesehatan }\end{array}$ \\
\hline 11 & $\begin{array}{l}\text { Melakukan } \\
\text { penggerindaan }\end{array}$ & $\begin{array}{l}\text { Ruang } \\
\text { penggerindaan } \\
\text { tidak luas }\end{array}$ & $\begin{array}{l}\text { Mata pedas, } \\
\text { dan iritasi }\end{array}$ & Dirujuk ke RS & $\begin{array}{l}\text { Pekerja } \\
\text { dibawa ke } \\
\text { ruang } \\
\text { kesehatan }\end{array}$ \\
\hline 12 & Rolling plate & $\begin{array}{l}\text { Tidak memakai } \\
\text { APD kacamata }\end{array}$ & $\begin{array}{l}\text { Mata pedas, } \\
\text { mata iritasi, } \\
\text { infeksi mata }\end{array}$ & Dirujuk ke RS & $\begin{array}{l}\text { Pekerja } \\
\text { dibawa ke } \\
\text { ruang } \\
\text { kesehatan }\end{array}$ \\
\hline 13 & Finishing & $\begin{array}{l}\text { Kurang hati-hati } \\
\text { dan kurang fokus }\end{array}$ & $\begin{array}{l}\text { Gigi patah, } \\
\text { bagian kepala } \\
\text { terasa sakit }\end{array}$ & $\begin{array}{l}\text { Dirujuk ke RS dan } \\
\text { diperbolehkan pulang }\end{array}$ & $\begin{array}{l}\text { Pekerja } \\
\text { dibawa ke } \\
\text { ruang } \\
\text { kesehatan }\end{array}$ \\
\hline
\end{tabular}


Tabel 3. Identifikasi Hazard dan Risk (lanjutan)

\begin{tabular}{|c|c|c|c|c|c|}
\hline No & Task & Hazard & Consequence & Action & Recovery \\
\hline 14 & $\begin{array}{l}\text { Melakukan } \\
\text { penggerindaan }\end{array}$ & $\begin{array}{l}\text { Tidak memakai } \\
\text { kaos tangan }\end{array}$ & $\begin{array}{l}\text { Timbulnya } \\
\text { luka robek }\end{array}$ & $\begin{array}{l}\text { Pemberian pertolongan } \\
\text { pertama pada } \\
\text { kecelakaan }\end{array}$ & $\begin{array}{l}\text { Pekerja } \\
\text { dibawa ke } \\
\text { ruang } \\
\text { kesehatan }\end{array}$ \\
\hline 15 & Packing & $\begin{array}{l}\text { Beban cukup } \\
\text { tinggi tidak } \\
\text { menggunakan } \\
\text { sarung tangan }\end{array}$ & $\begin{array}{l}\text { Timbulnya } \\
\text { luka goresan } \\
\text { pada tangan }\end{array}$ & $\begin{array}{l}\text { Pemberian pertolongan } \\
\text { pertama pada } \\
\text { kecelakaan }\end{array}$ & $\begin{array}{l}\text { Pekerja } \\
\text { dibawa ke } \\
\text { ruang } \\
\text { kesehatan }\end{array}$ \\
\hline 16 & Packing & Kurang hati-hati & $\begin{array}{l}\text { Jari telunjuk } \\
\text { robek, tulang } \\
\text { retak }\end{array}$ & $\begin{array}{l}\text { Pemberian pertolongan } \\
\text { pertama pada } \\
\text { kecelakaan }\end{array}$ & $\begin{array}{l}\text { Pekerja } \\
\text { dibawa ke } \\
\text { ruang } \\
\text { kesehatan }\end{array}$ \\
\hline 17 & $\begin{array}{l}\text { Melakukan } \\
\text { proses } \\
\text { pengelasan }\end{array}$ & $\begin{array}{l}\text { Sempitnya ruang } \\
\text { pengelasan } \\
\text { karena dalam can }\end{array}$ & Mata iritasi & $\begin{array}{l}\text { Pemberian pertolongan } \\
\text { pertama pada } \\
\text { kecelakaan }\end{array}$ & $\begin{array}{l}\text { Pekerja } \\
\text { dibawa ke } \\
\text { ruang } \\
\text { kesehatan }\end{array}$ \\
\hline 18 & Packing & $\begin{array}{l}\text { Pekerja tidak } \\
\text { paham dengan } \\
\text { tools yang ada }\end{array}$ & $\begin{array}{l}\text { Kening } \\
\text { terluka, bibir } \\
\text { bengkak }\end{array}$ & $\begin{array}{l}\text { Pemberian pertolongan } \\
\text { pertama pada } \\
\text { kecelakaan }\end{array}$ & $\begin{array}{l}\text { Pekerja } \\
\text { dibawa ke } \\
\text { ruang } \\
\text { kesehatan }\end{array}$ \\
\hline 19 & $\begin{array}{l}\text { Pengepressan } \\
\text { besi }\end{array}$ & $\begin{array}{l}\text { Beban kerja } \\
\text { cukup tinggi dan } \\
\text { pekerja kurang } \\
\text { konsentrasi }\end{array}$ & $\begin{array}{l}\text { Jempol } \\
\text { terluka dan } \\
\text { bengkak }\end{array}$ & $\begin{array}{l}\text { Pemberian pertolongan } \\
\text { pertama pada } \\
\text { kecelakaan }\end{array}$ & $\begin{array}{l}\text { Pekerja } \\
\text { dibawa ke } \\
\text { ruang } \\
\text { kesehatan }\end{array}$ \\
\hline 20 & $\begin{array}{l}\text { Melakukan } \\
\text { pelubangan } \\
\text { pada besi }\end{array}$ & $\begin{array}{l}\text { Pinggiran besi } \\
\text { tajam }\end{array}$ & $\begin{array}{l}\text { Tumit kiri } \\
\text { tergores }\end{array}$ & $\begin{array}{l}\text { Pemberian pertolongan } \\
\text { pertama pada } \\
\text { kecelakaan }\end{array}$ & $\begin{array}{l}\text { Pekerja } \\
\text { dibawa ke } \\
\text { ruang } \\
\text { kesehatan }\end{array}$ \\
\hline 21 & $\begin{array}{l}\text { Melakukan } \\
\text { pelubangan } \\
\text { pada besi }\end{array}$ & $\begin{array}{l}\text { Sisi besi yang } \\
\text { tajam }\end{array}$ & $\begin{array}{l}\text { Luka gores } \\
\text { pada tangan }\end{array}$ & $\begin{array}{l}\text { Pemberian pertolongan } \\
\text { pertama pada } \\
\text { kecelakaan }\end{array}$ & $\begin{array}{l}\text { Pekerja } \\
\text { dibawa ke } \\
\text { ruang } \\
\text { kesehatan }\end{array}$ \\
\hline 22 & $\begin{array}{l}\text { Cutting } \\
\text { marking }\end{array}$ & $\begin{array}{l}\text { Jarak antar } \\
\text { matras dan } \\
\text { pemotongan } \\
\text { plasma terlalu } \\
\text { dekat }\end{array}$ & $\begin{array}{l}\text { Mata iritasi } \\
\text { parah dan } \\
\text { luka bakar } \\
\text { pada bagian } \\
\text { muka }\end{array}$ & $\begin{array}{l}\text { Dirujuk ke RS khusus } \\
\text { mata }\end{array}$ & $\begin{array}{l}\text { Pekerja } \\
\text { dibawa ke } \\
\text { ruang } \\
\text { kesehatan }\end{array}$ \\
\hline 23 & $\begin{array}{l}\text { Melakukan } \\
\text { penggerindaan }\end{array}$ & $\begin{array}{l}\text { Menggerinda } \\
\text { tanpa cover } \\
\text { gerinda }\end{array}$ & $\begin{array}{l}\text { Luka gores } \\
\text { pada tangan }\end{array}$ & $\begin{array}{l}\text { Pemberian pertolongan } \\
\text { pertama pada } \\
\text { kecelakaan }\end{array}$ & $\begin{array}{l}\text { Pekerja } \\
\text { dibawa ke } \\
\text { ruang } \\
\text { kesehatan }\end{array}$ \\
\hline 24 & $\begin{array}{l}\text { Melakukan } \\
\text { penggerindaan }\end{array}$ & $\begin{array}{l}\text { Menggerinda } \\
\text { tanpa cover } \\
\text { gerinda }\end{array}$ & $\begin{array}{l}\text { Menimbulkan } \\
\text { luka robek }\end{array}$ & $\begin{array}{l}\text { Pemberian pertolongan } \\
\text { pertama pada } \\
\text { kecelakaan }\end{array}$ & $\begin{array}{l}\text { Pekerja } \\
\text { dibawa ke } \\
\text { ruang } \\
\text { kesehatan }\end{array}$ \\
\hline
\end{tabular}


Tabel 3. Identifikasi Hazard dan Risk (lanjutan)

\begin{tabular}{|c|c|c|c|c|c|}
\hline No & Task & Hazard & Consequence & Action & Recovery \\
\hline 25 & $\begin{array}{l}\text { Melakukan } \\
\text { penggerindaan }\end{array}$ & $\begin{array}{l}\text { Tidak memakai } \\
\text { kacamata safety }\end{array}$ & $\begin{array}{l}\text { Mata perih } \\
\text { dan iritasi }\end{array}$ & $\begin{array}{l}\text { Pemberian pertolongan } \\
\text { pertama pada } \\
\text { kecelakaan }\end{array}$ & $\begin{array}{l}\text { Pekerja } \\
\text { dibawa ke } \\
\text { ruang } \\
\text { kesehatan }\end{array}$ \\
\hline 26 & $\begin{array}{l}\text { Melakukan } \\
\text { penggerindaan }\end{array}$ & $\begin{array}{l}\text { Tidak memakai } \\
\text { gloves }\end{array}$ & $\begin{array}{l}\text { Menimbulkan } \\
\text { luka robek }\end{array}$ & $\begin{array}{l}\text { Pemberian pertolongan } \\
\text { pertama pada } \\
\text { kecelakaan }\end{array}$ & $\begin{array}{l}\text { Pekerja } \\
\text { dibawa ke } \\
\text { ruang } \\
\text { kesehatan }\end{array}$ \\
\hline 27 & $\begin{array}{l}\text { Cutting } \\
\text { marking }\end{array}$ & $\begin{array}{l}\text { Tidak memakai } \\
\text { gloves }\end{array}$ & $\begin{array}{l}\text { Menimbulkan } \\
\text { luka tersayat }\end{array}$ & $\begin{array}{l}\text { Pemberian pertolongan } \\
\text { pertama pada } \\
\text { kecelakaan }\end{array}$ & $\begin{array}{l}\text { Pekerja } \\
\text { dibawa ke } \\
\text { ruang } \\
\text { kesehatan }\end{array}$ \\
\hline 28 & Packing & $\begin{array}{l}\text { Kurangnya } \\
\text { konsentrasi } \\
\text { sehingga terkena } \\
\text { palu }\end{array}$ & $\begin{array}{l}\text { Menimbulkan } \\
\text { luka memar } \\
\text { dan nyeri }\end{array}$ & $\begin{array}{l}\text { Pemberian pertolongan } \\
\text { pertama pada } \\
\text { kecelakaan }\end{array}$ & $\begin{array}{l}\text { Pekerja } \\
\text { dibawa ke } \\
\text { ruang } \\
\text { kesehatan }\end{array}$ \\
\hline 29 & $\begin{array}{l}\text { Material } \\
\text { handling }\end{array}$ & $\begin{array}{l}\text { Jumlah beban } \\
\text { over dan } \\
\text { kurangnya } \\
\text { komunikasi }\end{array}$ & $\begin{array}{l}\text { Luka retak } \\
\text { pada tulang } \\
\text { jari tangan }\end{array}$ & Dirujuk ke RS & $\begin{array}{l}\text { Pekerja } \\
\text { dibawa ke } \\
\text { ruang } \\
\text { kesehatan }\end{array}$ \\
\hline 30 & $\begin{array}{l}\text { Melakukan } \\
\text { proses gerinda } \\
\text { penggerindaan }\end{array}$ & $\begin{array}{l}\text { Kacamata safety } \\
\text { dilepas }\end{array}$ & $\begin{array}{l}\text { Mata pedas } \\
\text { dan iritasi }\end{array}$ & Dirujuk ke RS & $\begin{array}{l}\text { Pekerja } \\
\text { dibawa ke } \\
\text { ruang } \\
\text { kesehatan }\end{array}$ \\
\hline 31 & $\begin{array}{l}\text { Melakukan } \\
\text { proses gerinda }\end{array}$ & $\begin{array}{l}\text { Ruang kurang } \\
\text { luas }\end{array}$ & $\begin{array}{l}\text { Daerah mata } \\
\text { pedas dan } \\
\text { iritasi }\end{array}$ & $\begin{array}{l}\text { Pemberian pertolongan } \\
\text { pertama pada } \\
\text { kecelakaan }\end{array}$ & $\begin{array}{l}\text { Pekerja } \\
\text { dibawa ke } \\
\text { ruang } \\
\text { kesehatan }\end{array}$ \\
\hline 32 & $\begin{array}{l}\text { Melakukan } \\
\text { proses gerinda }\end{array}$ & $\begin{array}{l}\text { Kacamata safety } \\
\text { dilepas }\end{array}$ & $\begin{array}{l}\text { Daerah mata } \\
\text { pedas dan } \\
\text { iritasi }\end{array}$ & $\begin{array}{l}\text { Pemberian pertolongan } \\
\text { pertama pada } \\
\text { kecelakaan }\end{array}$ & $\begin{array}{l}\text { Pekerja } \\
\text { dibawa ke } \\
\text { ruang } \\
\text { kesehatan }\end{array}$ \\
\hline
\end{tabular}

Selanjutnya adalah melakukan stratifikasi atau penggolongan terhadap jenis-jenis hazard yang terjadi sehingga dapat diketahui potensi bahaya apa yang paling dominan dan sering terjadi di perusahaan ini. Tools yang digunakan adalah diagram pareto seperti pada Gambar 1. Pada grafik pareto dibawah dapat disimpulkan bahwa jenis kecelakaan kerja yang paling dominan adalah terpercik dimana diikuti oleh tergores, terjepit, terbentur, tertimpa, kecetit, dan tersayat. Dari hasil berikut maka jenis kecelakaan kerja terpercik geram akan ditinjau lebih lanjut.

Setelah didapati jenis hazard yang paling dominan, maka selanjutnya yang dilakukan adalah analisa menggunakan risk matriks mengenai faktor-faktor penyebab kecelakaan terpercik. Dari faktor- faktor penyebab kecelakaan kemudian dilakukakan penetuan dari setiap nilai severity $(\mathrm{S})$ dan occurance $(\mathrm{O})$ melalui metode brainstorming dengan staff yang menangani kecelakaan kerja diperusahaan baja pada workshop 1 dan 2. Hasil yang didapat akan ditempatkan pada risk matriks sesuai dengan ranking yang telah diberikan pada tiap matriks resiko. Tabel 4 merupakan penentuan kriteria ranking yang akan memberikan hasil penyebab kecelakaan kerja yang paling dominan yaitu jenis kecelakaan kerja 
terpercik. Setelah tabel kriteria terbentuk maka dibuatlah risk matriks pada tabel 5 sesuai dengan nilai ranking untuk menunjukkan warna yang sesuai sehingga mempermudah proses analisa.

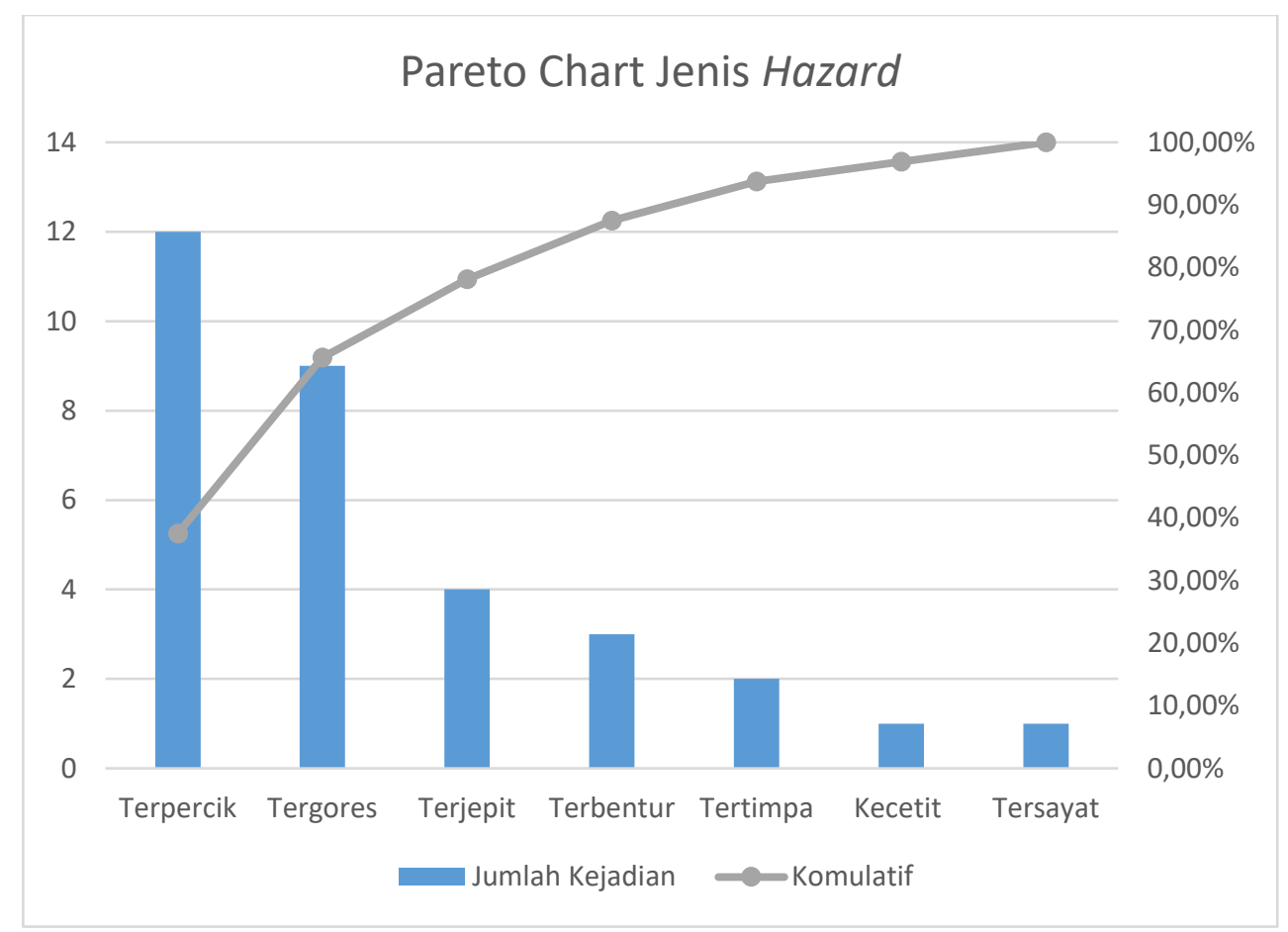

Gambar 1. Diagram Pareto

Tabel 4. Penentuan Kriteria Ranking Severity dan Ranking Occurance

\begin{tabular}{|c|c|c|c|c|}
\hline $\begin{array}{c}\text { Kejadian } \\
\text { Kecelakaan } \\
\text { Kerja }\end{array}$ & Indikator & Faktor Penyebab & $\mathbf{S}$ & $\mathbf{O}$ \\
\hline \multirow{11}{*}{$\begin{array}{l}\text { Mata kemasukan } \\
\text { geran dan } \\
\text { terpercik }\end{array}$} & \multirow{4}{*}{ Manusia } & Pekerja tidak menggunakan APD yang disediakan & 3 & 5 \\
\hline & & Misscommunication antar pekerja & 2 & 3 \\
\hline & & Pekerja yang kurang profesional & 2 & 3 \\
\hline & & Mengabaikan SOP perusahaan & 4 & 2 \\
\hline & Metode & $\begin{array}{l}\text { Proses penggerindaan yang mepet dengan tinggi badan } \\
\text { pekerja }\end{array}$ & 4 & 3 \\
\hline & \multirow{2}{*}{ Mesin } & Pelepasan cover gerinda & 4 & 3 \\
\hline & & Mata gerinda yang materialnya jelek & 2 & 3 \\
\hline & Peralatan & $\begin{array}{l}\text { Tidak disediakannya APD yang memadai di seluruh proses } \\
\text { yang ada pada perusahaan }\end{array}$ & 2 & 2 \\
\hline & \multirow{3}{*}{ Lingkungan } & Jam kerja yang terlalu berlebih & 3 & 3 \\
\hline & & Suara berisik pada bagian produksi & 2 & 2 \\
\hline & & Ruang penngerindaan sempit pada saat di dalam can & 3 & 3 \\
\hline
\end{tabular}

Dari hasil pengolahan data di atas dapat diketahui bahwa kecelakaan kerja yang terjadi pada perusahaan fabrikasi baja dalam kurun waktu setahun terakhir terhitung mulai Januari - Oktober 2018 terjadi beberapa jenis kecelakaan kerja yaitu terpercik, tergores, terjepit, terbentur, tertimpa, kecetit, dan tersayat. Dengan menggunakan diagram pareto dapat diketahui dengan jelas bahwa jenis kecelakaan kerja yang paling dominan adalah pekerja terkena percikan gram pada mata dengan total kejadian sebanyak 12 kali. Jenis kecelakaan kerja yang dominan kemudian yang akan diteliti lebih lanjut menggunakan ranking tingkat keparahan dan tingkat kemungkinan terjadinya. 
Tabel 5. Risk Matriks Faktor Utama Penyebab Mata Terpercik Geram

\begin{tabular}{|c|c|c|c|c|c|}
\hline \multirow{2}{*}{$\begin{array}{l}\text { Jumlah } \\
\text { kejadian }\end{array}$} & \multicolumn{5}{|c|}{ Tingkat keparahan (severity) } \\
\hline & 1 & 2 & 3 & 4 & 5 \\
\hline 5 & & & $\begin{array}{l}\text { Tidak melengkapi diri } \\
\text { dengan APD }\end{array}$ & & \\
\hline 4 & & & & & \\
\hline 3 & & $\begin{array}{l}\text { - Amatir } \\
\text { - Miscomunication antar } \\
\text { pekerja } \\
\text { - Mata gerinda material nya } \\
\text { buruk }\end{array}$ & $\begin{array}{l}\text { - Jam kerja yang terlalu } \\
\text { tinggi } \\
\text { - Ruang penggerindaan } \\
\text { yang kurang memadai di } \\
\text { dalam can }\end{array}$ & $\begin{array}{l}\text { - Proses gerinda yang } \\
\text { terlalu mepet dengan } \\
\text { tinggi badan manusia } \\
\text { - Pelepasan cover } \\
\text { gerinda }\end{array}$ & \\
\hline 2 & & $\begin{array}{l}\text { - Tidak disediakannya APD } \\
\text { yang memadai di seluruh } \\
\text { proses yang ada pada } \\
\text { perusahaan } \\
\text { - Suara berisik pada bagian } \\
\text { produksi }\end{array}$ & & $\begin{array}{l}\text { - Mengabaikan } \\
\text { prosedur } \\
\text { Kerja }\end{array}$ & \\
\hline 1 & & & & & \\
\hline
\end{tabular}

Dari beberapa faktor tersebut akan diolah lebih lanjut menggunakan matriks resiko yaitu dengan menilai berdasarkan tingkat keparahan (severity) dan tingkat kemungkinan terjadi (occurance) sehingga didapatkan hasil sebagai berikut:

a. Resiko sedang (warna kuning) meliputi suara bising di line produksi, pekerja yang baru masuk atau bisa diartikan pegawai amatir, jam kerja yang berlebihan, mengabaikan prosedur kerja, jam kerja yang telalu tinggi dan lokasi penggerindaan yang kurang luas yang berada didalam can. Enam faktor diatas termasuk dalam kategori risiko sedang yang memerlukan tindakan untuk dikurangi tingkat risikonya, akan tetapi sebaiknya biaya pencegahan harus tetap diperhitungkan dengan teliti dan se efisien mungkin. Selain itu pada tingkat resiko ini, harus ada penetapan lama waktu dalam pengukuran pengurangan risiko.

b. Resiko tinggi (warna jingga) meliputi proses penggerindaan overhead, bahan mata gerinda memiliki kualitas yang buruk, pelepasan cover gerinda, dan tidak melengkapai diri dengan APD. Empat hal tersebut termasuk dalam kategori risiko tinggi dimana kegiatan tidak boleh dilaksanakan sebelum faktor - faktor tersebut mampu disolusikan.

Jadi dengan menggunakan penilaian pada matriks risiko dapat dilihat bahwa faktor faktor yang mempengaruhi kecelakaan kerja mata terpercik geram adalah dikarenakan para pekerja yang tidak melengkapi diri dengan APD yang sesuai yaitu kacamata. Dari hasil tersebut pekerja tidak memakai alat pelindung diri setelah dicari akar penyebabnya, didapatkan hasil penyebabnya dan berikut hasilnya sebagai berikut:

a. Pada kategori human, para pekerja teridentifikasi merasa kurang nyaman jika memakai alat pelindung diri yaitu kacamata safety, kacamata ini dirasa mengurangi aktivitas gerak pekerja, anggapan bahwa job desc tersebut tidak menimbulkan bahaya, rendahnya bahwa alat pelindung diri itu penting.

b. Pada kategori metode, pihak manajemen yang kurang tegas dan kurangnya sanksi yang diberikan bagi pelanggar menyebabkan hal ini masih terus terjadi

c. Pada kategori material, kacamata mudah menimbulkan bekas goresan sehingga mengurangi pengelihata dari pekerja. 


\section{Kesimpulan}

Dari penelitian ini didapatkan bahwa kecelakaan yang paling dominan di perusahaan fabrikasi baja ini adalah terpercik geram yang didapatkan dari hasil stratifikasi dengan 32 tabel hazop. Hal ini dipertegas dengan disajikannya diagram pareto pada gambar 1. yang menunjukkan jenis kecelakaan terpecik merupakan jenis kecelakaan dominan.

Penyebab utama dari kecelakaan paling dominan pada penelitian ini adalah para pekerja yang tidak melengkapi diri dengan APD pada saat bekerja yaitu kacamata, dimana hasil risk matriks menunjukkan warna jingga. Hal ini didapatkan setelah melakukan investigasi dengan angka Severity dan Occurance setelah dilakukan stratifikasi hazard serta pembuatan diagram pareto. Tabel HAZOP sangat membantu dalam pengumpulan data hazard perusahaan berdasarkan alur produksi sehingga dapat disimpulkan bahwa hazard paling tinggi di perusahaan adalah terpercik geram.

\section{Daftar Pustaka}

Dunjó, J., Fthenakis, V., Vílchez, J. A., dan Arnaldos, J. (2010). Hazard and operability (HAZOP) analysis. A literature review'. Journal of Hazardous Materials, Vol. 173, No. 1-3, hal. 19-32. doi: 10.1016/j.jhazmat.2009.08.076.

Febriyan, D., Anindita, G., dan Mayangsari, N. E. (2017). Analisis potensi bahaya menggunakan metode HAZOP dan Fuzzy Layer of Protection Analysis pada Desiccant Dehydration Unit di PT Lapindo Brantas, inc. Seminar Nasional K3 PPNS 2017, Vol 1, No. 1, hal. 328-333.

Hamdy, M. I. dan Tanjung, L. S. (2016). Analisa potensi bahaya dan upaya pengendalian kecelakaan kerja pada proses penambangan batu adesit di PT. Dempo Bangun Mitra. Jurnal Teknik Industri: Jurnal Hasil Penelitian dan Karya Ilmiah dalam Bidang Teknik Industri, Vol. 2, No. 2, hal. 148154. doi: 10.24014/jti.v2i2.5101.

Khamid, A., Mulyadi, Y. and Mukhtasor, M. (2019). Analisa risiko keselamatan dan kesehatan kerja (K3) terhadap kecelakaan kerja serta lingkungan dengan menggunakan metode Hazard and Operability Study (HAZOP) pada proses scrapping kapal. Jurnal Teknik ITS, Vol. 7, No. 2, hal. 38. doi: 10.12962/j23373539.v7i2.33216.

Kotek, L. dan Tabas, M. (2012). HAZOP Study with Qualitative Risk Analysis for Prioritization of Corrective and Preventive Actions. 20th International Congress of Chemical and Process Engineering CHISA 2012, hal. 808-815. (Prague, 25-29 Agustus 2012). doi: 10.1016/j.proeng.2012.07.473.

Restuputri, D. P. dan Sari, R. P. D. (2015). Analisis Kecelakaan Kerja Dengan Menggunakan Metode Hazard and Operability Study (Hazop). Jurnal Ilmiah Teknik Industri, Vol. 14, No. 1, hal. 24-35. 